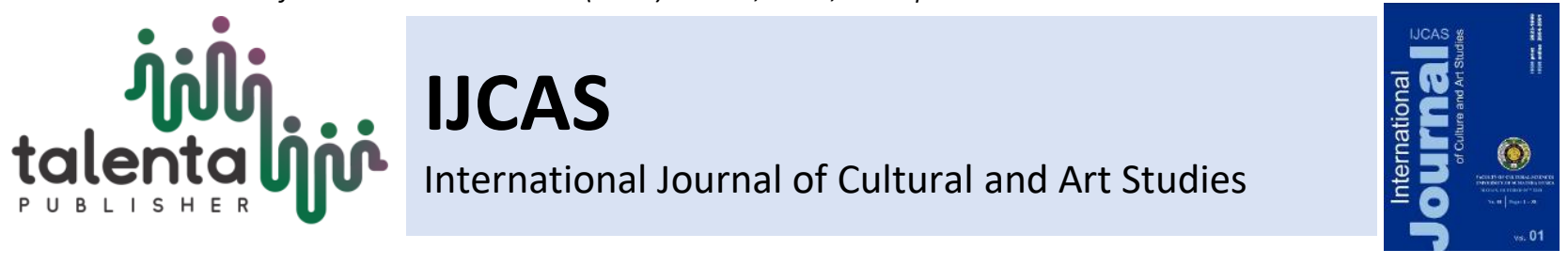

\title{
Assessing the Process Not Just the Message: A Cursory View of Student Assessment
}

\author{
Liza Amalia Putri ${ }^{1 *}$ and Jacki Bustos ${ }^{2}$ \\ ${ }^{1}$ University of Sumatera Utara, Indonesia, \\ ${ }^{2}$ Purdue University, USA
}

\begin{abstract}
Knowing the tremendous importance of the grade, we spent several weeks discussing, researching, and writing about the process of assessing student work. As we evaluated the written work of Claire Evelyn, an eighteen-year-old, second-semester freshman enrolled in ENGL 112, Composition and Literature, at a regional campus in Ohio, we were able to balance the enormous weight of assessing Evelyn's work with the growing confidence in our skills. Our confidence stemmed from reading, understanding, and applying the composition theory found in our collaborative research. The particular assignment that we are assessing includes a unit of writing comprised of a final portfolio, dialogue journal, and Evelyn's reflective letter. We will discuss the general justification and reasoning of our assessment based on the theory of process grading, rubrics, and of course, Evelyn's written text. After some deliberation and through the use of the rubric we established, we settled on a $\mathrm{C}+$ for Claire. As we began this research, our initial reaction was to grade the final draft without considering the other materials. Upon further discussion and research, we collectively decided to broaden our scope and include the reflection journal and the dialogue letters. By extending the text beyond one draft, we were able to give her a grade more fitting for the scope of her writing.
\end{abstract}

Keywords: Assessment, Student's Writing, Writing Process

Received [15 May 2018] | Revised [24 July 2018] | Accepted [15 August 2018]

\section{Introduction}

The responsibility of responding and assessing student work is, by far, the most important duty of the college instructor. The value the instructor places on student work will determine not only the course grade for the student, but also is a factor in future scholarships, financial aid packages, and possible admission to graduate school. Knowing the tremendous importance of the grade, we spent several weeks discussing, researching, and writing about our process of assessing student work. As we evaluated the written work of Claire Evelyn, an eighteen-yearold, second-semester freshman enrolled in ENGL 112, Composition and Literature, at a regional campus in Ohio, we were able to balance the enormous weight of assessing Evelyn's work with

\footnotetext{
*Corresponding author at: Department of English Faculty of Cultural Sciences University Of Sumatra Utara, Medan, Indonesia 20155. 
the growing confidence in our skills. Our confidence stemmed from reading, understanding, and applying the composition theory found in our collaborative research. The particular assignment that we are assessing includes a unit of writing comprised of a final portfolio, dialogue journal, and Evelyn's reflective letter. In this writing we will discuss: the general justification and reasoning of our assessment based on the theory of process grading, rubrics, and of course, Evelyn's written text.

\section{Process Grading}

We opted to grade this writing project as a portfolio. A portfolio grade would allow us to evaluate the student's process including other written texts such as the reflection essay and the student/instructor dialogue journals. This would give us a more well-rounded view of Evelyn's writing ability in various contexts. The concept of process (portfolio) grading is supported by Peggy O'Neill in her article, From the Writing Process to the Responding Sequence: Incorporating Self-Assessment and Reflection in the Classroom. She calls upon Kathleen Yancey's research to justify her use of self-assessment and grading, "Of course, the reflective writing the student has done all semester - usually graded minimally like a journal or free writing - has been counted as part of the necessary process work for each major writing assignment" (68). Such practice aligns with our decision to assign points for process and individualizes instruction. Our individualization of process grading based on the contractual ideology supports Elbow's theories on assessment expressed in his article Ranking, Evaluating, and Liking, "I often vary the criteria in my grid (e.g. rubric) depending on the assignment or the point in the semester" (195). Since various assignments and various students call for different modes of response, to follow an unmodified version of a predetermined contract or rubric does not get the job done. Additionally, such standards can be set up for the entire class to ensure process points are given to students while the focus stays on responding, revising, and improving. Linking such process points with outcomes-based assessments yields interesting results as well.

Though our purposes and goals for process grading here deal with finite measures, the same practice could be applied elsewhere. Process grading also allows for students who complete work which on initial reading might appear incompetent to reflect and argue for competence.

Claire's dialogue journals and reflective letter allow us to use a broader system under which to grade. In our case, these tools are tools for responding and learning. Though the final product is graded on a rubric, the process not the product is emphasized. For these reasons, Claire gets her credit for completing the process of revision without any fear of getting points removed. As Edward White points out in his article The Scoring of Writing Portfolios: Phase 2: 
But there is another way to score portfolios, much more in tune with the purpose and design of portfolio assessment. This method requires the development of two new documents as part of the assessment: first, a set of goals set by faculty for the particular course, program, or purpose for which the portfolio is submitted; and second, a reflective letter to readers composed by the student, and argument showing that those goals have been met (or, perhaps, not met), using the portfolio contents as evidence. (586)

To follow White's recommendation, we have (as mentioned above) set goals for Claire within her assignment framework. These goals are outlined on a rubric. Therefore, our final grade will be based on the process (portfolio) points and a rubric. Our process points are working similarly to a grading contract. Since Claire participated in dialogue through journaling and because she participated in reflection through a letter, those points become process points. Her completion of both activities reflects part of the grade itself. Jane Danielewicz and Peter Elbow discuss their implementation of grading contracts, "Jane and Peter essentially use the same contract for their first-year writing courses" (245). Interestingly enough, Danielewicz uses the contract for an honors program, imparting the impression that such practices do not indicate lower standards, which is a general woe in the path of contractual grading progress and other similar practices. They go on to explain that each student receives a B if they follow a list of instructions. Out of the list provided by Danielewicz, we have found three points relevant to our assessment of Evelyn:

1. Complete all informal, low-stakes writing assignments (e.g., journal writing or discussionboard writing);

2. Give thoughtful peer feedback during class workshops and work faithfully with your group on other collaborative tasks (e.g., sharing papers, commenting on drafts, peer editing, online discussion boards);

3. Submit your midterm and final portfolio. (245-246)

We have chosen these few elements on which to base our process grading since it best fits our current situation and context. We found that customization of Elbow's contract fit this particular portfolio and prompt better than taking Elbow's contract at face value.

\section{Rubric}

We decided to write a general rubric that would have a greater implication for future projects as well as fit this particular writing process of Evelyn's. The rubric, in our minds, showed Claire's final paper to be about $\mathrm{C}$ level, before it was given to the rest of the group for rework and further discussion. This grade was without the rest of the process. Since we are evaluating the entire process not just the final paper, we knew her final grade would receive a slight bump up. 
Earlier we mentioned that Claire's final product in response to the prompt did not fulfill the requirements of the assignment. While this is true, her final product does at least hint at competency. Her expression of innocence and experience suggests that while she prefers to think of innocence as a loss, experience is an inescapable part of life, "I realize however that experience to some extent, is ultimately inevitable in living through the struggles of the world of damnation and that time stands still for no one. "Earlier she states, "Innocence, is far better than that of the experiencing of reality. "These statements, as ambiguous as they are, suggest competence. The second selection from her writing comes as close to answering the prompt as she gets. The reader can infer that she believes the movement of innocence to experience is a loss, but her narrative does not explicitly pull the idea to life. She also seems to implicitly assert that without the experience she would not be the woman she is currently. Though her narrative is befuddling, her reflective letter serves as a means to the instructor to give her a fairer grade.

Jeffrey Sommers supports the use of such reflective practices in his classroom. Like White, Sommers employs metacognitive assignment which he calls a student-teacher memo, to foster student participation: "The student-teacher memo is one method of enlisting that participation. In this approach, the instructor makes an assignment for writing and simultaneously makes an assignment for a student-teacher memo: a brief, informal not-to-be-graded communication written to the instructor by the student who comments on the draft in question" (329). By implementing such a method, Sommers allows for students to reflect throughout, like the dialogue journals in Claire's case. His suggestion of not grading such assignments is what fueled our decision to count Claire's dialogue journals and reflective letters as process points. Any discrepancies on the paper which are not covered or may seem unfair based on Claire's inability to complete the assignment properly will be reflected on the rubric.

We noticed Evelyn's writing gained in strength through her dialogue journals and reflective memo despite Evelyn's personal realization that she "did have something to share with the reader, feelings and convictions to contribute." Her idea of teasing out that "experience is necessary" in her paper comes to life in her reflective letter. By writing such a letter, the reader/instructor sees real growth from Claire. Even if she could not decide on which side to argue for her assignment, her reflective letters show growth which, maybe not coincidentally, coincides with her final answer to the prompt: "I, as an adult, now recognize my individual desire and responsibility to establish and promote competence and self-reliance to the best of my ability as an educator." Not only is Claire affirming her belief that experience is gainful, she is moving her writing to a point where she is metacognitive enough for her to realize how it affects her life and potential future experience as an educator. She has become the experience in a sense. Such insightful commentary proves that assigning process points to her reflective writing makes sense. What she lacks in convention, organization, and cohesion in her final 
product and reflective piece, is made up for with growth and owning and understanding her individual learning process.

Even though Evelyn showed growth as a writer as evidenced in her dialogue journals and reflective memo, she did not fulfill the requirements of the actual prompt. Her goal was to answer the question: "How should we view changing from being innocent to being experienced - as a loss or as a gain?" Though some implications of her possible response might lurk within her final paper, the outcome, or product, does not fulfill the assignment requirements. Without context, and inside the vacuum of a short, non-descriptive prompt, Claire's paper seems to fall well below competent for a college freshman. When her final product is contextualized, though, the reader, teacher, or author gains the ability to assess the writing from a new perspective. Determining a grade of $\mathrm{C}+$ weighs softer with the inclusion of dialogue journals and a reflective letter.

\section{Grade Outcome}

During the first read through of Claire's essay, the reader is overwhelmed with the inability to locate the purpose or message partly due to the overwhelming grammatical and punctuation errors and partly due to the disorganization and focus of the essay. Since our first roadblock to understanding Claire's message is her murky grammar and punctuation, we have chosen to begin our discussion with Claire's non-mastery of these lower order skills.

Claire makes frequent punctuation errors; she does not indicate possession with an apostrophe ("My grandfather's death ....), she places commas awkwardly ("I would know as many other children, experience the loss ...., "I realize however that experience to some extent, is ultimately inevitable ...") and she is inconsistent in her use of hyphens ("As wide eyed youngsters . . ."but later on the same page "The once wide-eyed child now was gone ..."). She uses redundant structures ("At the age of eight years old . ..") and makes awkward word choices ("Despite to some, the delusional prospect of material wealth . .."). Her memories of childhood seem sentimental —almost mawkish — and the cited poetry seems forced, as if included only to satisfy a prompt. The poems are introduced with awkward transitions that ring false ("As I weep for the loss of my own childhood I recall the poem 'Piano' by D.H. Lawrence.”, “Likewise Robert Frost in his poem, 'Birches' escapes from the burdens of reality to the happy memories of childhood.").

Taken on its own with no context, this is a poor paper that seems to deserve a poor grade. But we are not left to take this paper at face value. We have context, in the form of Claire's correspondence with her instructor through a dialogue journal. Through this dialogue, Claire opens up about her fears of writing poorly and her admiration of those who write well, and her 
instructor encourages her to risk failure by letting her initial drafts be poor and trusting the revision process:

Dialogue Journal \#1

[Claire] I find it difficult to open up in any form of communication to others, but I will do my best Professor Sommers. I find writing one of the most frightening and exhausting experiences possible.

[Professor] Perhaps knowing that you can revise your papers will help you relax more as you write them. Since first drafts don't equal final drafts (in "real life") or in this class, don't strive for perfection in that 1 st draft. The only failed first draft is the one that doesn't lead to a second draft.

The context we gain by reading this ongoing dialogue between Claire and her teacher is valuable, and it must be included in our final evaluation of her paper. Work does not exist in a vacuum, and we cannot simply disregard our new understanding of Claire's anxiety and struggle with writing for an audience. As we re-read Claire's final draft, we should follow Irmscher's advice in "Evaluation", and "suppress our usual tendency to attack weakness" (152).

In "Ranking, Evaluating, and Liking," Peter Elbow gives the examples of reviewing our own work and having mixed reactions, and trying to apply that mix of love and hate to a student's work that we are tasked with evaluating. After reading the piece and the added context, Claire's work seems to fall in the "This is terrible . . But I like it. Damn it, I'm going to get it good enough so that others will like it too" (199). Elbow claims that "[g]ood teachers see what is only potentially good, they get a kick out of mere possibility — and they encourage it" (200). As we reread Claire's essay with an eye to liking it instead of judging it, we find that there are moments of surprising competence in all three areas that we found lacking earlier. "It was a brisk, clear January morning when my grandfather and I walked for the last time out the back door of the old country farm house which I had grown to love and know so well" is a structural sound and evocative sentence. There is good writing just out of reach in Claire's description of her last day with her grandfather:

"At the age of eight years old I would never after this day know such simplicity and whole-hearted happiness again. I would know as many other children, experience the loss of a loved one. My grandfather's death brought overwhelming anguish and pain to a world once filled with innocent joy and light-heartedness. The once wide-eyed child now was gone forever never to return." 
Claire may be suppressing something powerful here in service of the prompt. She seems to be rushing through a poignant story to get to the mandatory poetry, and that may be squeezing the life out of an insightful piece of writing. Without access to earlier drafts, it is impossible to know what role the instructor played to bring us to this final draft, but there seems to be the raw material for something extraordinary in Claire's work. But this is not a draft. This is a final piece. And with that comes a demand to assign a grade, which feels like an end, not a beginning. We want to encourage Claire to revise the piece, to keep writing, to continue opening up and communicating with others, but standing in the way of that is a letter we must put on her paper that will almost certainly obscure any notes or advice. Claire's paper is competent in some small areas; it suggests competence in many others. The "right" grade for this paper is probably a C, but we like Claire and want to encourage her so a B feels better. It's possible to ride the fence and give her a B-/C+, but that seems unsatisfying. It seems as if we were unable or unwilling to decide.

Since riding the fence seems unsatisfying, we are stuck in the unpleasant situation of getting off the fence on one side or the other. Both sides have merits and could be justified. A B-would probably be more encouraging to Charlene, and since she seems keenly aware of the flaws in her writing, she may be a harsher critic of them than we could be; however, it may be too encouraging, giving her the false impression that her final piece was competent in and of itself, and not that it was part of an overall pattern of growth and potential. On the other hand, the fact that she is aware that her writing contains flaws does not mean that she knows what they are or how to correct them. A "fairer" and less "generous" grade of C+ may disappoint her initially, but her dissatisfaction with the grade may cause her to look at our advice more carefully. After some deliberation and through the use of the rubric we established, we settled on a $\mathrm{C}+$ for Claire.

\section{Concluding Remarks}

As we began this project, our initial reaction was to grade the final draft without considering the other materials. Upon further discussion and research, we collectively decided to broaden our scope and include the reflection journal and the dialogue letters. By extending the text beyond one draft, we were able to give her a grade more fitting for the scope of her writing. 
That grade is a $\mathrm{C}+$. Overall, this process was enlightening and challenging.

Table 1. Rubric Grading and Movement into Process Grading

\begin{tabular}{|c|c|c|c|c|c|}
\hline & 5 Exemplary & 4 Understanding & 3 Competent & 2 Developing & 1 Beginning \\
\hline Focus: & $\begin{array}{l}\text { The student's writings } \\
\text { fit the prompt and went } \\
\text { beyond with additional } \\
\text { readings and } \\
\text { experiences that } \\
\text { brought new light to } \\
\text { the paper. }\end{array}$ & $\begin{array}{l}\text { The student } \\
\text { wrote a paper } \\
\text { that followed all } \\
\text { the guidelines } \\
\text { given but did little } \\
\text { to add more to } \\
\text { the work. }\end{array}$ & $\begin{array}{l}\text { The student } \\
\text { covered most } \\
\text { of the } \\
\text { requirements } \\
\text { and did so in a } \\
\text { way that } \\
\text { suggested they } \\
\text { understood the } \\
\text { prompt. }\end{array}$ & $\begin{array}{l}\text { The student wrote a } \\
\text { paper that had the } \\
\text { subject, but did not } \\
\text { follow the prompt } \\
\text { or did not meet the } \\
\text { requirements in } \\
\text { another way. }\end{array}$ & $\begin{array}{l}\text { The student did } \\
\text { not turn in a } \\
\text { paper or did not } \\
\text { attempt to } \\
\text { meet the } \\
\text { requirements. }\end{array}$ \\
\hline $\begin{array}{l}\text { Developm } \\
\text { ent: }\end{array}$ & $\begin{array}{l}\text { The student came in to } \\
\text { talk with the instructor } \\
\text { about the paper and } \\
\text { took suggestions to } \\
\text { heart through the rest } \\
\text { of his paper. }\end{array}$ & $\begin{array}{l}\text { The student came } \\
\text { in and talked } \\
\text { about his paper, } \\
\text { but only worked } \\
\text { on some of the } \\
\text { problems that } \\
\text { were noticed in } \\
\text { the paper. }\end{array}$ & $\begin{array}{l}\text { The student } \\
\text { may have come } \\
\text { in once, but } \\
\text { there was at } \\
\text { least one } \\
\text { rewrite created } \\
\text { to improve the } \\
\text { piece. }\end{array}$ & $\begin{array}{l}\text { The student could } \\
\text { recognize mistakes } \\
\text { during the time with } \\
\text { the instructor, but } \\
\text { was unwilling to } \\
\text { correct them or } \\
\text { work beyond the } \\
\text { first draft. }\end{array}$ & $\begin{array}{l}\text { The student did } \\
\text { not turn in a } \\
\text { paper or did not } \\
\text { attempt to } \\
\text { meet the } \\
\text { requirements. }\end{array}$ \\
\hline Audience: & $\begin{array}{l}\text { The paper was written } \\
\text { in a way that was easy } \\
\text { to read and was clearly } \\
\text { written to benefit the } \\
\text { correct audience, both } \\
\text { in word choice and in } \\
\text { experiences shared. }\end{array}$ & $\begin{array}{l}\text { The work was } \\
\text { written in a way } \\
\text { that covered the } \\
\text { prompt and } \\
\text { allowed the } \\
\text { audience to } \\
\text { understand what } \\
\text { was being } \\
\text { communicated. }\end{array}$ & $\begin{array}{l}\text { The audience } \\
\text { had difficulty } \\
\text { relating to the } \\
\text { work because } \\
\text { of word choice } \\
\text { or the way } \\
\text { experiences } \\
\text { were shown to } \\
\text { them. }\end{array}$ & $\begin{array}{l}\text { The audience felt } \\
\text { alienated by the } \\
\text { piece because of } \\
\text { word choice and } \\
\text { experiences shared. } \\
\text { The author clearly } \\
\text { did not take the } \\
\text { audience into } \\
\text { consideration. }\end{array}$ & $\begin{array}{l}\text { The student did } \\
\text { not turn in a } \\
\text { paper or did not } \\
\text { attempt to } \\
\text { meet the } \\
\text { requirements. }\end{array}$ \\
\hline
\end{tabular}

Appendix 1 Rubric Grading and Movement into Process Grading

\section{REFERENCES}

[1] Elbow, Peter. "A Unilateral Grading Contract to Improve Learning and Teaching [co-written with Jane Danielewicz]." UMass Amberst English Department Faculty Publication Series. Paper 3. January 2008. 1 March 2014. Web.

[2] Elbow, Peter. "Ranking, Evaluating, and Liking: Sorting out Three Forms of Judgment." College English, Vol. 55, No. 2 (Feb. 1993); 187-206. 1 March 2014. Web.

[3] Irmscher, William. Teaching Expository Writing. New York: Holt, Rinehart and Winston. 1979. Print.

[4] O’Neill, Peggy. "From the Writing Process to the Responding Sequence: Incorporating SelfAssessment and Reflection in the Classroom." Teaching English in the Two-Year College, Vol. 26, No. 1 (Sep. 1998); 61-70. 1 March 2014. Web.

[5] Sommers, Jeffrey. "Enlisting the Writer's Participation in the Evaluation Process." Journal of Teaching Writing 4.1 (Spring 1985). Reprinted in Straub, Key Works 328-335. Print.

[6] White, Edward. "The Scoring of Writing Portfolios." College Composition and Communication, Vol. 56, No. 4 (June 2005); 581-600. 1 March 2014. Web. 